\title{
Analisis Hukum Pelaksanaan Penyelesaian Sengketa Bisnis Dengan Metode Arbitrase Online di Indonesia dan di Singapura
}

\author{
Yongky Pieter Lahema ${ }^{1}$, Imam Haryanto ${ }^{2}$ \\ ${ }^{1,2}$ Faculty of Law, Universitas Pembangunan Nasional Veteran Jakarta \\ Jl. RS. Fatmawati Raya, Pd. Labu, Kec. Cilandak, Kota Depok, Jawa Barat 12450 \\ *Correspondence email: yongky.pieter99@gmail.com; imam.upns1@gmail.com
}

\begin{abstract}
Abstrak. Arbitrase online sudah dilakukan oleh Singapore International Arbitration Centre (SIAC), lalu SIAC Rules, Arbitration Act of Singapore, dan UNCITRAL sebagai landasan hukum SIAC sudah memiliki aturan mengenai arbitrase online. Badan Arbitrase Nasional Indonesia (BANI) secara praktik sudah melaksanakan arbitrase online, namun dalam Peraturan \& Prosedur Arbitrase BANI dan Undang-Undang No.30 Tahun 1999 sebagai landasan hukum BANI belum memiliki aturan yang jelas. Penulisan ini akan membahas tentang perbandingan pelaksaaan arbitrase online di SIAC dengan BANI, bagaimana SIAC mengatur pelaksanaan arbitrase online dan apakah dapat diadopsi untuk pengaturan pelaksanaan arbitrase online di BANI. Penelitian ini dilakukan dengan metode yuridis normatif. Pendekatan yang digunakan adalah perundang-undangan dan perbandingan. Hasil penelitian perbandingan pelaksanaan arbitrase online di SIAC dan BANI, bahwa SIAC sudah memiliki aturan yang mengatur pelaksanaan arbitrase online secara jelas dari pendaftaran arbitrase, hearing, sampai putusan arbitrase online. Pada pelaksanaan arbitrase online di BANI, pendaftaran arbitrase online BANI memungkinkan untuk dilaksanakan karena memiliki aturannya, namun dalam proses selanjutnya sidang pemeriksaan online, dan putusan arbitrase online belum memiliki aturan yang mengatur secara tegas dan jelas. Pengaturan arbitrase online di SIAC, dapat diadopsi menjadi hukum acara arbitrase online oleh BANI maupun Undang-Undang Arbitrase Indonesia karena tidak bertentangan dengan Undang-Undang lain yang ada di Indonesia.
\end{abstract}

Kata Kunci: Arbitrase online; Singapore International Arbitration Centre (SIAC); Badan Arbitrase Nasional Indonesia (BANI)

Abstract. Online arbitration has been carried out by the Singapore International Arbitration Center (SIAC), then SIAC Rules, Arbitration Act of Singapore, and UNCITRAL as a legal basis SIAC already has rules regarding online arbitration. The Indonesian National Arbitration Board (BANI) has practically carried out online arbitration, but the BANI Arbitration Rules \& Procedures and Law No.30 of 1999 as the legal basis for BANI do not have clear rules. This writing will discuss the comparison of online arbitration enforcement at SIAC with BANI, how SIAC regulates online arbitration execution and whether it can be adopted for online arbitration arrangements at BANI. This research was conducted using a normative juridical method. The approach used is legislation and comparison. The results of the comparative research on the implementation of online arbitration at SIAC and BANI show that SIAC already has rules that clearly regulate the implementation of online arbitration from arbitration registration, hearings, to online arbitration awards. In the implementation of online arbitration at BANI, BANI online arbitration registration is possible because it has the rules, but in the subsequent process of online examination hearings, and online arbitration awards do not yet have rules that regulate explicitly and clearly. Online arbitration arrangements at SIAC can be adopted into online arbitration procedure law by BANI and the Indonesian Arbitration Law because they do not conflict with other laws in Indonesia.

Keywords: Online Arbitration; Singapore International Arbitration Center (SIAC); Indonesian National Arbitration Agency (BANI)

\section{PENDAHULUAN}

Perkembangan dunia bisnis sangatlah pesat dan semakin banyak ragamnya. Hal itu terjadi karena semakin majunya era globalisasi di bidang teknologi yang tanpa batas, maka dari itu ada kemungkinan timbul permasalahan akibat wanprestasi yang dilakukan oleh para pihak. Beragam sengketa yang timbul dari kegiatan bisnis atau aktivitas komersial itu secara umum disebut sengketa bisnis atau sengketa komersial. ${ }^{1}$ Secara umum, masyarakat Indonesia menyelesaikan sengketa perdagangan yang terjadi melalui musyawarah. Jika kesepakatan antara para pihak atau salah satu pihak tidak tercapai selama proses peninjauan, sengketa tersebut dapat diselesaikan melalui jalur hukum, yaitu melalui prosedur peradilan.

Penyelesaian sengketa melalui litigasi atau lembaga peradilan memiliki efek hukum yang lebih besar dan mengikat para pihak yang bersengketa, karena lembaga peradilan merupakan lembaga hukum dan resmi yang dapat diselesaikan sesuai prosedur formal yang diatur dalam hukum acara untuk menyelesaikan perselisihan dimasyarakat. ${ }^{2}$

${ }^{1}$ Eman Suparman. Pilihan Forum Arbitrage Dalam Sengketa Komersil (untuk Penegakan Keadilan) (Jakarta: Tatanusa, 2004), hlm.5. hlm.78.

${ }^{2}$ Suyud Margono. Penyelesaian Sengketa Bisnis: Alternatif Dispute Resolutions (ADR) (Bogor: Ghalia Indonesia, 2010), 
Namun, penyelesaian sengketa koemrsial yang dilakukan dalam penelitian menunjukkan litigasi pengadilan dianggap memberikan keuntungan rendah baik bagi peserta komersial maupun konsumen perorangan. Selain mahal, prosesnya juga panjang dan rumit. Kepercayaan netral pelaku usaha dan masyarakat terletak pada fakta bahwa pengadilan tidak mendukung pemilihan pengadilan. ${ }^{3}$

Saat menyelesaikan sengketa komersial di dalam pengadilan, biasanya mempertimbangkan terlebih dahulu untuk penyelesaian sengketa komersial di luar pengadilan, yaitu melalui arbitrase atau penyelesaian sengketa alternatif. Saat menyelesaikan sengketa komersial melalui arbitrase, itu harus didasarkan pada persetujuan para pihak yang bersengketa. Pihak yang bersengketa dapat memilih seorang arbitrator untuk menyelesaikan sengketa komersial yang diselesaikan melalui arbitrase. Arbitrase adalah metode penyelesaian sengketa, dengan perkembangan perdagangan dan investasi internasional, metode ini semakin banyak digunakan, ${ }^{4}$ dan keberadaannya dinilai sebagai metode penyelesaian sengketa yang fleksibel, karena siapa pun dapat dengan bebas menggunakan dan menentukan arah pelaksanaannya. ${ }^{5}$ Dengan kata lain arbitrase Ini adalah proses yang sederhana dan mudah, para pihak secara sukarela memilih pihak-pihak yang menginginkan juru sita yang netral memutuskan perkara mereka berdasarkan pilihan mereka sendiri, keputusan mereka didasarkan pada dalil-dalil perkara. Para pihak sejak awal setuju untuk menerima keputusan secara final dan mengikat. ${ }^{6}$

Berdasarkan data yang dirilis Asosiasi Penyelenggara Jasa Internet Indonesia (APJII), hingga akhir tahun 2018, pengguna Internet Indonesia telah mencapai 171,17 juta atau $64,8 \%$ dari total penduduk yang berjumlah 264,16 juta jiwa di Indonesia. ${ }^{7}$ Oleh karena itu, tidak menutup kemungkinan adanya perselisihan antar pengguna jasa internet yang mengalami perselisihan dalam lalu lintas komunikasi elektronik online. Misalnya sengketa tentang transaksi online atau biasa disebut dengan e-commerce. Sengketa elektronik yang terjadi secara online di Internet mungkin tidak segera diselesaikan melalui jalur litigasi. Ini karena proses penyelesaiannya memakan waktu lama, dan sengketa ecommerce terus bermunculan dari waktu ke waktu.

Oleh karena itu, metode baru telah dikembangkan, yang sekarang disebut arbitrase online, untuk menyelesaikan sengketa yang timbul dari perbuatan hukum elektronik, terutama sengketa lainnya. Namun, hal tersebut masih sebatas sengketa yang memang bisa diselesaikan melalui prosedur alternatif penyelesaian sengketa berdasarkan undangundang.

Perkembangan teknologi yang semakin kompleks, yang juga mengarah pada arbitrase yang dapat dilakukan secara online melalui internet, yang akan sangat membantu kedua belah pihak dari segi waktu dan biaya. Dunia virtual yang dibangun melalui internet antara suatu negara dengan negara lain. Karena kemudahan teknologi informasi, internet tidak hanya digunakan sebagai satu-satunya alat komunikasi, dan juga untuk perdagangan. ${ }^{8}$

Penggunaan arbitrase online sebagai penyelesaian sengketa diluar pengadilan dapat menjadi salah satu cara mengatasi jika dalam suatu keadaan memang harus menggunakan fasilitas internet. Seperti yang terjadi pada tahun 2020 ini yaitu adanya peristiwa pandemi Corona Virus Desease 2019 (Covid-19), akibatnya hampir semua aktivitas manusia dilakukan secara online.

Badan Arbitrase Nasional Indonesia (BANI) merupakan salah satu lembaga arbitrase nasional yang banyak dipilih oleh para pelaku bisnis dan telah menyesuaikan pelaksanaan arbitrase pada masa pandemi dengan mengeluarkan Surat Keputusan No. 20.015/V/SK-BANI/HU tentang aturan dan prosedur arbitrase elektronik. Untuk memberikan kepastian hukum kepada para pihak yang bersengketa, BANI telah menyesuaikan para pihak untuk melakukan virtual trial pada platform yang disepakati bersama. Dengan demikian, para pihak yang melaksanakan proses penyelesaian sengketa tetap dapat beroperasi dan tidak terhalang oleh pandemi Covid-19. ${ }^{9}$

${ }^{3}$ Ibid., 87.

4 Alan Redfern dan J. Martin Hunter. Redfern and Hunter on International Arbitration, ed. keenam, (Inggris: Oxford University Press, 2015), hlm.1.

${ }^{5}$ Doug Jones, "Comments on the Speech of the Singapore Attorney General", dalam International Arbitration: The Coming of a New Age?, (2013), hlm. 30.

${ }^{6}$ Salim H.S., Hukum Kontrak Teori Teknik Penyusunan Kontrak, Cet. Ke-3, (Jakarta: Grafika, 2006), hal.142.

${ }^{7}$ Asosiasi Penyelenggara Jasa Internet Indonesia, Statistik Indonesia https://www.apjii.or.id/content/read/39/410/Hasil-Survei-Penetrasi-dan-Perilaku-Pengguna-Internet-Indonesia-2018, diakses tanggal 17 Maret 2020 Pukul 20.56 WIB.

${ }^{8}$ Electronic Commerce can be defined as commercial activities conducted through an exchange of information generated, stored, or communicated by electronical, optical or analogues means, including EDI, E-mail, and so forth. Lihat di Hill, Richard and Ian Walden, The Draft UNCITRAL Model Law for Electronic Commerce : Issues and solutions ( teaching materials ) March 1996.

${ }^{9}$ Hukum Online, Penyesuaian Pelaksanaan Proses Arbitrase Kala Pandemi Covid-19 Oleh: Harri Budiman \& Maria Ulfa, https://www.hukumonline.com/berita/baca/lt5fe2c3fab0c93/penyesuaian-pelaksanaan-proses-arbitrase-kala-pandemi-covid19-oleh--harri-budiman-maria-ulfa?page=all, diakses tanggal 25 Januari 2021 Pukul 20:35 
Namun sama halnya dengan penyelesaian sengketa bisnis dilakukan di Singapore International Arbitration Centre (SIAC), bahwa di SIAC sudah menjalankan penyelesaian sengketa secara online sejak adanya pandemi. SIAC memastikan bahwa proses persidangan arbitrase akan tetap berjalan, sebagaimana tertulis dalam laman resmi SIAC bahwa "SIAC arbitrations are continuing subject to the prevailing COVID-19 situation where the parties, counsels, and tribunal are located". Adapun pelaksanaan proses arbitrase peraturan SIAC (SIAC Rules) sudah mengatur penyelesaian sengketa bisnis dengan arbitrase online.

Dalam penulisan ini akan dibahas 2 (dua) lembaga arbitrase, yakni Badan Arbitrase Nasional Indonesia (selanjutnya disebut dengan BANI) dan Singapore International Arbitration Centre (selanjutnya disebut dengan SIAC). Oleh karena itu dalam konteks itulah penulis ini berupaya membahas beberapa hal yang berkaitan dengan bagaimana perbandingan pelaksanaan arbitrase online di Indonesia melalui lembaga BANI dan di SIAC, dan apakah SIAC rules dapat dijadikan model hukum acara di Indonesia mengenai pelaksanaan arbitrase online. Diharapkan uraian dalam artikel ini dapat memberikan pembahasan yang lebih jelas tentang arbitrase online, sejauh mana undangundang yang ada mengatur penyelesaian sengketa komersial melalui internet, dan kemungkinan penggantian sengketa komersial melalui arbitrase online dapat diterapkan di Indonesia. Melalui arbitrase online ini, ke depannya akan memberikan yurisdiksi kepada masyarakat, terutama justice seeker (pencari keadilan), solusi baru untuk menyelesaikan sengketa di masa mendatang.

\section{METODE}

\section{Jenis Penelitian}

Penelitian hukum ini menggunakan metode hukum yuridis normatif. Penelitian hukum normatif yang nama lainnya adalah penelitian hukum doktrinal yang disebut juga sebagai penelitian perpustakaan atau studi dokumen karena penelitian ini dilakukan atau ditujukan hanya pada peraturan-peraturan yang tertulis atau bahan-bahan hukum yang lain. ${ }^{10}$ Pada intinya penelitian yang dilakukan dengan cara meneliti bahan-bahan pustaka atau data sekunder yang terdiri dari bahan hukum primer, bahan hukum sekunder dan bahan hukum tertier.

\section{Pendekatan Masalah}

Adapun pendekatan yang digunakan penulis adalah pendekatan perundang-undangan (statute approach) dan Pendekatan perbandingan (Comparative approach) . Pendekatan perundangan-undangan adalah pendekatan yang dilakukan dengan menelaah semua undang-undang dan regulasi yang bersangkut paut dengan isu hukum yang ditangani. Pendekatan perbandingan adalah pendekatan yang dilakukan untuk membandingkan hukum suatu negara dengan hukum negara lain

\section{Teknik Pengumpulan dan Alat Bahan Hukum}

Teknik pengumpulan bahan hukum dimaksudkan untuk memperoleh bahan hukum dalam penelitian. Teknik pengumpulan bahan hukum yang mendukung dan berkaitan dengan pemaparan penelitian ini adalah studi dokumen (studi kepustakaan). Studi dokumen adalah suatu alat pengumpulan bahan hukum yang dilakukan melalui bahan hukum tertulis dengan mempergunakan content analisys. ${ }^{11}$ Teknik ini berguna untuk mendapatkan landasan teori dengan mengkaji dan mempelajari buku-buku, peraturan perundang-undangan, dokumen, laporan, arsip dan hasil penelitian lainnya baik cetak maupun elektronik yang berhubungan dengan pelaksanaan arbitrase online di Indonesia dan di SIAC.

\section{HASIL DAN PEMBAHASAN \\ Pelaksanaan arbitrase online di SIAC dan di BANI}

Penyelesaian sengketa dalam dunia bisnis merupakan suatu hal yang harus dilakukan secara cepat dan tepat. Penyelesaian sengketa bisnis melalui pengadilan dianggap kurang tepat dan efektif. Penyelesaian sengketa bisnis melalui lembaga peradilan dianggap tidak efektif karena proses penyelesaian perkara yang lambat, memakan waktu lama, dan mahal, lembaga peradilan tidak peka terhadap kepentingan umum, putusan pengadilan tidak dapat menyelesaikan sengketa, dan kapabilitas hakim bersifat generalis dan biasanya mengeluarkan putusan itu dibuat tanpa pertimbangan yang masuk akal. Bertolak dari alasan tersebut pentingnya penggunaan model Alternatif Dispute Resolution (ADR) yang menyangkut penyelesaian sengketa yang bersifat "out of court settlement model" terutama

${ }^{10}$ Soerjono Soekanto, dan Sri Mamudji, Penelitian Hukum Normatif, Cetakan ke-8, (Jakarta: PT. Raja Grafindo Persada, 2004), hlm.14.

${ }^{11}$ Ibid., hlm. 21. 
Yongky Pieter Lahema dan Imam Haryanto, Analisis Hukum Pelaksanaan Penyelesaian Sengketa Bisnis dengan Metode Arbitrase Online di Indonesia dan di Singapura

terhadap bisnis. ${ }^{12}$ Penyelesaian sengketa bisnis melalui pengadilan ditempatkan sebagai ultimum remedium bagi penyelesaian sengketa bisnis. ${ }^{13}$

Menurut Undang-Undang Nomor 30 tahun 1999 tentang Arbitrase dan Alternatif Penyelesaian Sengketa, yang dimaksud dengan arbitrase termuat dalam Pasal 1 angka 1 yang berbunyi, "Arbitrase adalah cara penyelesaian suatu sengketa perdata diluar peradilan umum yang didasarkan pada perjanjian arbitrase yang dibuat secara tertulis oleh para pihak yang dalam suatu perjanjian tertulis bersangkutan". Perjanjian yang dimaksud diatur dalam Pasal 1 angka 3 yang berbunyi, "Perjanjian arbitrase adalah suatu kesepakatan berupa klausul arbitrase yang tercantum dan dibuat para pihak sebelum sengketa atau suatu perjanjian arbitrase tersendiri yang dibuat para pihak setelah timbul sengketa."

Online Dispute Resolution (ODR) yaitu metode penyelesaian sengketa yang sama dengan metode ADR (Alternative Dispute Resolution). Yang membedakan hanya terletak pada mekanismenya yaitu secara online. Semua bentuk Alternative Dispute Resolution tradisional terwakili jaringan. ${ }^{14}$

Dalam pelaksanaan prosedur arbitrase, landasan hukum sangat penting dan menjadi dasar bagi prosedur arbitrase. Pada penulisan ini, penelitian ini akan menjelaskan dasar hukum dari prosedur arbitrase online BANI dan SIAC. Dan pada artikel ini juga akan dijelaskan informasi tentang proses arbitrase online dan contoh klausul yang digunakan di BANI dan SIAC.

Landasan hukum yang digunakan oleh BANI adalah Undang-Undang Nomor 30 Tahun 1999 tentang Arbitrase dan Alternatif Penyelesaian Sengketa. Hal ini didasarkan pada Konvensi New York 1958 (Convention on the recgnition and Enforcement of Foreign Arbitral Awards) yang telah diratifikasi atau disetujui melalui Keputusan Presiden Nomor 34 Tahun 1981. Jika dalam kontrak terdapat suatu klausula yang mengatur mengenai arbitrase maka penyelesaian sengketa dapat dilakukan di BANI dan kedua belah pihak sepakat untuk menggunakan penyelesaian sengketa melalui arbitrase. ${ }^{15}$ Namun dalam hal ini BANI mempunyai suatu peraturan tersendiri yaitu Peraturan Prosedur Arbitrase BANI yang mengatur mengenai prosedur jalannya arbitrase di BANI dan yang keputusannya mengikat kedua belah pihak yang bersengketa sebagai keputusan tingkat pertama dan terakhir.

Sedangkan dasar hukum yang menjadi landasan pelaksanaan arbitrase yang dilakukan oleh SIAC sesuai dengan forum arbitrase (baik di Singapura maupun di luar Singapura). Jika forum arbitrase berada di Singapura maka hukum yang berlaku adalah Undang-undang Arbitrase (Arbitration Act, Cap 10, 2002, Rev Ed/Arbitration Act) atau Undangundang Arbitrase Internasional (International Arbitration Act, Cap 143 A/IAA) ${ }^{16}$ SIAC juga dapat mengatur arbitrase menggunakan aturan hukum lainnya yang disetujui oleh para pihak, misalnya Peraturan Arbitrase UNCITRAL Tahun 2010 (UNCITRAL Arbitration Rules 2010). ${ }^{17}$ UNCITRAL adalah aturan arbitrase yang berasal dari Resolusi Sidang Umum PBB pada tanggal 15 Desember 1976. Di dalamnya terdapat aturan arbitrase yang dianggap dapat diterima oleh semua pihak di dunia internasional dengan sistem hukum sosial yang berbeda, terutama dalam penyelesaian sengketa. Dan aspek-aspek yang terkait dengan perdagangan internasional.

Dalam hal ini, mekanisme pelaksanaan arbitrase SIAC memiliki aturannya sendiri, yaitu Arbitration Rules of the Singapore International Arbitration Centre (SIAC Rules). SIAC Rules diterbitkan pada tanggal 1 Juli 2010, dan telah diperbarui pada 1 Agustus 2016, dengan pembaruan SIAC Rules Jilid ke-6. SIAC akan selalu memperbaharui regulasinya, Update yang diharapkan memuat beberapa klausul yang inovatif dan perkembangan hukum acara yang ada, sehingga diharapkan client mendapatkan rangkaian hukum acara yang efektif, efisien dan mudah dipahami sesuai dengan kebutuhan para pihak. ${ }^{18}$

Arbitrase online sama dengan arbitrase biasa, yang membedakan hanya metode yang digunakan yaitu sarana elektronik yang digunakan dalam pelaksanaannya. Dalam arbitrase online, pendaftaran perkara, pemilihan arbiter, pengambilan keputusan, penyerahan dokumen, musyawarah arbiter, pengambilan keputusan dan pemberitahuan pengambilan keputusan semuanya dilakukan secara online.

${ }^{12}$ H.M Erham Amin dan Mulyani Zulaeha, Penyelesaian Sengketa Perdata Melalui Arbitrase Online Dalam Konstruksi Undang-Undang Nomor 30 Tahun 1999 tentang Arbitrase dan Alternatif Penyelesaian Sengketa, Magister Ilmu Hukum, Universitas Lambung Mangkurat, (2011).

${ }^{13}$ M. Yahya Harahap, Arbitrase, Cetakan ke-3, Edisi ke-2, (Jakarta: Penerbit Sinar Grafika, 2004), hal.75.

${ }^{14}$ Gabrielle Kaufmann-Kohler dan Thomas Schultz, Online Dispute Resolution: Challenges For Contemporary Justice, Kluwer Law Internasional, The Netherlands, 2004, hlm. 11.

${ }^{15}$ Lihat Undang-undang Nomor 30 Tahun 1999 tentang Arbitrase dan Alternatif Penyelesaian Sengketa, UU. Nomor 30, LN. Nomor 138, Tahun 1999, TLN Nomor 3872, Pasal 3.

16 SIAC, “Rules”, https://www.siac.org.sg/our-rules, diakses tanggal 23 Januari 2021 Pukul 19:01 WIB.

${ }^{17}$ Frans Hendra Winarta. Hukum Penyelesaian Sengketa Arbitrase Nasional dan Internasional, Edisi ke-2, (Jakarta: Sinar Grafika, 2016), hal.163.

18 Hukum Online, "Simak, Delapan Perubahan Aturan Terbaru dalam SIAC Rules 2016", https://www.hukumonline.com/berita/baca/lt582d38404424c/simak--delapan-perubahan-aturan-terbaru-dalam-siac-rules-2016/, diakses tanggal 23 Januari 2021 Pukul 19:20 WIB 
Yongky Pieter Lahema dan Imam Haryanto, Analisis Hukum Pelaksanaan Penyelesaian Sengketa Bisnis dengan Metode Arbitrase Online di Indonesia dan di Singapura

Dalam pelaksanaan arbitrase online, para pihak yang akan menyelesaikan sengketa harus memperhatikan beberapa hal. Prosedur arbitrase SIAC adalah setiap pihak yang akan melakukan penyelesaian sengketa dengan arbitrase harus mematuhi ketentuan aturan SIAC Rules, begitu pula sebaliknya, setiap pihak yang menyelesaikan sengketa melalui arbitrase di BANI harus mematuhi ketentuan dalam Peraturan dan Prosedur Arbitrase BANI. Segala bentuk komunikasi dan perubahan terkait arbitrase yang dilakukan oleh SIAC harus dalam bentuk tertulis, dan batas waktunya akan ditentukan oleh majelis arbitrase SIAC. ${ }^{19}$ Jika terdapat klausul arbitrase dalam perjanjian kontrak, dan kedua belah pihak sepakat untuk menggunakan arbitrase untuk menyelesaikan sengketa, maka para pihak dapat menyelesaikan sengketa tersebut dengan BANI.

Dalam pelaksanaan arbitrase online urutan/tahapan pelaksanaan penyelesaian sengketa melalui lembaga arbitrase SIAC sesuai dengan Rules of Singapore International Arbitration Centre dibandingkan dengan BANI sesuai dengan Peraturan dan Prosedur Arbitrase BANI di antaranya:

\section{Pendaftaran Arbitrase online}

Sesuai dengan SIAC Rules Article 3.1 Pemohon (the "Claimant") harus memberikan permohonan (Notice of Arbitration) bentuk tertulis dimana permohonan tersebut berisikan: penyelesaian sengketa diselesaikan melalui arbitrase, identitas para pihak (nama, alamat, nomor telepon, e-mail untuk korespodensi), dan klausul arbitrase dalam perjanjian (dalam bentuk terpisah atau dalam bentuk gabungan) dalam perjanjian tersebut, penjelasan penyebab terjadinya perselisihan/sengketa, pernyataan yang menunjukan bahwa para pihak setuju untuk menggunakan arbitrase untuk menyelesaikan sengketanya, menunjuk/mengusulkan jumlah arbiter yang digunakan dalam penyelesaian, penggunaan dasar hukum, bahasa yang digunakan, dan pengajuan biaya arbitrase.

Dalam SIAC Rules Article 4.1 mengenai Jawaban (the "Respondent") yang diberikan oleh Claimant harus sudah dijawab oleh Respondent dalam waktu 14 (empat belas) hari setelah menerima Notice of Arbitration, surat jawaban tersebut berisikan: konfirmasi atau penolakan gugatan, pernyataan yang secara jelas menyatakan posisi dan keadaan gugatan, balasan dari pernyataan dalam Notice of Arbitration atau tanggapan lain terkain gugatan, apabila para pihak setuju, Respondent merekomendasikan siapa yang dipilih sebagai arbiter. Jawaban yang diberikan Respondent harus disertai dengan Statement of Defence (Pernyataan Pembelaan) dan Statement of Counterclaim (Gugatan Balik).

Dalam proses pemberitahuan arbitrase dan tanggapan terhadap pemberitahuan arbitrase di SIAC, SIAC melalui seminar "Mediasi \& Arbitrase Dalam Penyelesaian Sengketa Bisnis (Best Practice Di Indonesia \& Singapura)" dengan speaker Kendista Wantah, S.H., FCIArb. Counsel, Singapore International Arbitration Centre (SIAC) yang penulis hadiri, SIAC dalam pandemi COVID-19 telah menutup kantor sampai waktu yang ditentukan dan berimbas pada segala bentuk komunikasi termasuk pemberitahuan arbitrase dan tanggapan pemberitahuan arbitrase bahwa segala dilakukan secara online melalui via e-mail. Kemudian untuk pembayaran biaya pengajuan arbitrase, semua pembayaran ke SIAC diminta untuk dilakukan dengan electronic bank transfer (transfer via bank). ${ }^{20}$

Dan dipertegas kembali pada SIAC Rules bahwa SIAC dalam pendaftaran arbitrase dapat dilakukan secara online dapat dilihat pada SIAC Rules Article 2.1 yang berbunyi: ${ }^{21}$

"For the purposes of these Rules, any notice, communication or proposal shall be in writing. Any such notice, communication or proposal may be delivered by hand, registered post or courier service, or transmitted by any form of electronic communication (including electronic mail and facsimile), or delivered by any other appropriate means that provides a record of its delivery."

Dalam UNCITRAL Article 3(1)(a) Model Law relevantly states juga dijelaskan bahwa pendaftaran atau penyerahan pemberitahuan dan tanggapan arbitrase dapat dilakukan dengan sarana lain apabila dalam pengiriman surat ke tempat bisnis, alamat pribadi, jika tidak satupun dari ini dapat ditemukan setelah melakukan penyelidikan, maka diberikan opsi untuk memberikan berkas pendaftaran tersebut dengan upaya lain untuk mengirimkan berkas pendaftaran tersebut, yaitu dengan cara surat elektronik (e-mail).

Kemudian dalam Arbitration Act of Singapore Part II menjelaskan bahwa dalam pemberkasan dapat berupa "electronic communication" yang berarti setiap komunikasi yang dilakukan oleh para pihak dengan sarana pesan data atau electronic mail, telegram, telex atau telecopy.

Dari ketentuan SIAC Rules, Arbitration Act of Singapore, dan UNCITRAL tersebut menjelaskan bahwa dalam pemberitahuan, komunikasi atau proposal proses pemberitahuan arbitrase dan tanggapan memungkinkan dalam pengiriman tidak hanya dapat dilakukan secara penyerahan fisik surat, tetapi dijelaskan juga segala bentuk komunikasi

${ }^{19}$ Lihat Article 2.1 Singapore International Arbitration Centre Rules (SIAC Rules)

${ }^{20}$ Seminar "Mediasi \& Arbitrase Dalam Penyelesaian Sengketa Bisnis (Best Practice Di Indonesia \& Singapura) pada tanggal 11 September 2020.

${ }^{21}$ Lihat Rule 2.1 of the SIAC Rules relevantly states 
Yongky Pieter Lahema dan Imam Haryanto, Analisis Hukum Pelaksanaan Penyelesaian Sengketa Bisnis dengan Metode Arbitrase Online di Indonesia dan di Singapura

termasuk surat elektronik (e-mail) dan faksimili dapat dilaksanakan dengan menyediakan bukti pengiriman berkasberkas tersebut.

Pendaftaran dan Permohonan Arbitrase di BANI tidaklah jauh berbeda dengan di SIAC yaitu dimana para pihak yang akan melakukan penyelesaian sengketa dengan arbitrase memiliki perjanjian dimana dalam klausulnya terdapat mengenai klausula arbitrase. Sesuai dengan Peraturan \& Prosedur Arbitrase BANI Pasal 6 angka 1 sampai 5 prosedur arbitrase dimulai dengan Pemohon melakukan Pendaftaran dan Penyampaian Permohonan Arbitrase kepada sekertariat BANI, permohonan mengadakan arbitrase harus memuat: identitas para pihak yaitu nama dan alamat para pihak, perjanjian yang didalamnya terdapat klausula arbitrase, keterangan fakta-fakta dan dasar hukum permohonan arbitrase, rincian permasalahan, dan tututan dan/atau nilai tuntutan yang dimintakan. Penunjukan/usulan jumlah arbiter yang akan digunakan dalam penyelesaian tersebut, kemudian permohonan mengadakan arbitrase disertai dengan pembayaran biaya pendaftaran.

Selanjutnya Tanggapan Termohon dalam Peraturan \& Prosedur Arbitrase BANI dalam pasal 8 angka 1 sampai 4 setelah pendaftaran Permohonan tersebut telah disampaikan dan Dewan Pengurus BANI menentukan bahwa BANI berwenang memeriksa perkara tersebut, selanjutnya Sekertariat menyampaikan salinan Permohonan Arbitrase kepada Termohon, dan Termohon mengirimkan tanggapan tertulis dalam waktu 30 (tiga puluh) hari setelah menerima penyampaian Permohonan Arbitrase. Dalam Jawaban ini, Termohon dapat menunjuk seorang arbiter untuk digunakan dalam penyelesaian. ${ }^{22}$

Pelaksanaan arbitrase online pada proses Pendaftaran Arbitrase di BANI dapat dilakukan karena dalam Peraturan \& Prosedur Arbitrase BANI memiliki pasal yang mengatur tentang Pemberitahuan yang dapat dilakukan pengiriman Permohonan Arbitrase dan berkas-berkas lampirannya secara online yaitu terdapat dalam Pasal 4 angka 3 yang berbunyi: ${ }^{23}$

"Setiap pemberitahuan yang perlu disampaikan berdasarkan Peraturan dan Prosedur ini, kecuali Majelis Arbitrase atau Arbiter Tunggal menginstruksikan lain, harus disampaikan langsung, melalui kurir, faksimili atau e-mail dan dianggap berlaku pada tanggal diterima atau apabila tanggal penerimaan tidak dapat ditentukan, pada hari setelah penyampaian dimaksud. Apabila alamat Termohon tidak dapat ditemukan, pemberitahuan dapat disampaikan melalui Kelurahan tempat domisili terakhir Termohon yang diketahui berdasarkan informasi dari Pemohon".

Kemudian dalam Undang-Undang No.30 Tahun 1999 tentang Arbitrase Pasal 4 ayat 3 yang mengatakan dalam hal disepakati penyelesaian sengketa dalam bentuk pertukaran surat melalui bentuk pengiriman teleks, telegram, faksmili, e-mail, dan bentuk sarana komunikasi lainnya dapat dilakukan.

Dari ketentuan Peraturan \& Prosedur Arbitrase BANI dan Undang-Undang No. 30 Tahun 1999 tentang Arbitrase maka pengiriman perjanjian/pendaftaran arbitrase dapat dilakukan dengan melalui e-mail, melalui faksimili arbitrase, maupun melalui perantaraan post.

Dalam proses Pendaftaran Arbitrase online di SIAC maupun BANI masing masing lembaga arbitrase tersebut sudah mengakomodir para pihak yang ingin menyelesaikan perkara dengan cara arbitrase yang dilakukan secara online.

\section{Hearing/Sidang Pemeriksaan}

Tahap berikutnya diikuti dengan pembuktian-pembuktian oleh para pihak. Sebelum membahas proses pembuktian lebih lanjut, penulis akan memberikan pemahaman tentang pembuktian yang dikemukakan oleh beberapa ahli. Menurut Subekti yang dimaksud dengan pembuktian adalah untuk meyakinkan hakim bahwa dalil-dalil yang dikemukakan dalam persengketaan itu benar. ${ }^{24}$ Prof Dr. Supomo mengatakan, bahwa membuktikan memiliki arti yang luas dan terbatas.

Jika para pihak ingin proses pembuktian melalui saksi-saksi, maka persidangan akan diadakan. Proses sidang pemeriksaan hanya akan dilakukan jika salah satu atau kedua belah pihak meminta sidang. ${ }^{25}$

Dalam aturan SIAC Proses Pemeriksaan Perkara disebut dengan Hearing. Kewenangan ketua majelis arbitrase dalam menetapkan aturan-aturan prosedural dapat dilihat di SIAC Rules. SIAC Rules mendefinisikan kewenangan Ketua Majelis arbitrase dengan cara yang sedikit berbeda. Menurut SIAC Rules, Ketua Majelis arbitrase dapat

\footnotetext{
${ }^{22}$ Lihat Pasal 8 Undang-undang Nomor 30 Tahun 1999 tentang Arbitrase dan Alternatif Penyelesaian Sengketa

${ }^{23}$ Lihat Pasal 4 angka 3 Peraturan \& Prosedur Arbitrase BANI

${ }^{24}$ Riyeke Ustadiyanto, Framework E-commerce, (Bandung: Andi Offset, 2002), hal.124.

25 Paustinus Siburian, Arbitrase Online (Alternatif Penyelesaian Sengketa Perdagangan Secara Elektronik, (Jakarta:
} Tatanusa, 2004), hal.100. 
Yongky Pieter Lahema dan Imam Haryanto, Analisis Hukum Pelaksanaan Penyelesaian Sengketa Bisnis dengan Metode Arbitrase Online di Indonesia dan di Singapura

merumuskan aturan dan proseduralnya sendiri, tetapi Majelis arbitrase terbuka untuk merevisi. ${ }^{26}$ Dasar pemberian kewenangan tersebut adalah bahwa ketua majelis arbitrase harus dianggap sebagai orang yang bertanggung jawab dan profesional sehingga dapat melaksanakan prosedur arbitrase dengan majelis arbitrase baik dari segi teori, praktek dan efisiensi waktu dan biaya.

SIAC Rules menjamin kerahasiaan proses Hearing/proses pemeriksaan termasuk pertemuan-pertemuan yang dilakukan selama pemeriksaan, pemeriksaan saksi dan ahli, transkrip dokumen dokumen yang dipergunakan dalam pemeriksaan. ${ }^{27}$ Prosedur persidangan SIAC lebih menekankan pada kebenaran materiil (common law) karena banyak pihak asing yang menggunakan arbitrase SIAC. ${ }^{28}$

Pelaksanaan Hearing di SIAC bahwa SIAC sudah melaksanakannya secara online. Namun, jika para pihak setuju untuk melakukannya secara online, saksi dari para pihak tidak perlu menghadiri sidang arbitrase, dan cukup memberi tahu para pihak atau arbiter atau majelis arbitrase untuk mendengarkan kesaksian mereka melalui Video Conference atau Telephone yang diberikan.

Hal tersebut SIAC Rules sudah menyesuaikan peraturan dengan keadaan sehingga sudah mempunyai pengaturan mengenai pemeriksaan saksi-saksi secara online. Terdapat pada Rule 21.2 of the SIAC Rules States yang berbunyi : ${ }^{29}$

"The Tribunal may hold hearings and meetings by any means it considers expedient or appropriate and at any location it considers convenient or appropriate."

Dalam pasal pada SIAC Rules tersebut dapat diartikan majelis arbitrase dalam pemeriksaan saksi dapat mengadakan dengar pendapat dan pertemuan dengan cara apapun dan di lokasi mana pun yang dianggap nyaman atau tepat. Oleh karena itu memungkinkan Hearing dapat dilaksanakan secara online dengan Telephone, Video, Online Hearing, sesuai dengan kesepakatan para pihak bila ingin menjalankan proses Hearing dengan online.

Kemudian proses Hearing dengan metode online pun sudah diatur dalam UNCITRAL ditulis pada Article 24(1) of the UNCITRAL Model Law relevantly states: ${ }^{30}$

"Subject to any contrary agreement by the parties, the arbitral tribunal shall decide whether to hold oral hearings for the presentation of evidence or for oral argument, or whether the proceedings shall be conducted on the basis of documents and other materials."

Dipertegas lagi dengan pasal yang terdapat pada Arbitration Act of Singapore bahwa proses Hearing dapat dilakukan secara online yaitu pada Arbitration Act Chapter 10, Act 25(1) tentang Hearings and witten proccedings: ${ }^{31}$

"Subject to any contrary agreement by the parties, the arbitral tribunal shall determine if proceedings are to be conducted by oral hearing for the presentation of evidence or oral argument or on the basis of documents and other materials."

Dari ketentuan tersebut proses Hearing pada SIAC Rules, ,Arbitration Act of Singapore, dan UNCITRAL sudah mengatur mengenai pelaksanaanya secara online, dan dengan pelaksanaan proses Hearing secara online ini memiliki keuntungan bagi para pihak yaitu sangat ekonomis karena para pihak dan saksi-saksinya tidak perlu mengeluarkan biaya transport dan lainnya, dan sangat menghemat waktu karena dengan dilaksanakannya secara online bisa dilakukan dimana saja.

BANI menyebut proses ini dengan Sidang Pemeriksaan. Dalam Pasal 49 ayat 1 Undang-undang No. 30 Tahun 1999 tentang Arbitrase disebutkan bahwa seorang saksi atau lebih atau seorang saksi ahli atau lebih dapat dipanggil untuk didengar keterangannya yang mana pemanggilan tersebut dilakukan atas perintah arbiter atau permintaan para pihak. Adanya kata "Dapat" dapat diartikan bahwa jika memang para pihak menyetujui dan dipandang perlu maka arbiter dapat menghadirkan saksi serta saksi ahli tersebut. Secara lebih mengkhusus dalam Pasal 24 ayat 4 Peraturan \& Prosedur Arbitrase BANI yang menyatakan bahwa jika dianggap perlu maka para pihak serta arbiter dapat memanggil saksi atau ahli dimana hal tersebut dilakukan sebelum sidang pemeriksaan saksi yang diawali dengan pengajuan informasi serta identitas yang akan disampaikan secara tertulis.

\footnotetext{
${ }^{26}$ Lihat Article 16.5 Singapore International Arbitration Centre Rules (SIAC Rules)

${ }^{27}$ Lihat Article 21.4 Singapore International Arbitration Centre Rules (SIAC Rules)

${ }^{28}$ Frans Hendra Winarta, Op.Cit, hal. 131.

${ }^{29}$ Lihat Article 21.2 of the SIAC Rules states

${ }^{30}$ Lihat Article 24(1) of the UNCITRAL

${ }^{31}$ Lihat Act 25(1) Arbitration Act (Chapter 10)
} 
Pelaksanaan Sidang Pemeriksaan saksi di BANI, BANI memfasilitasi untuk diselanggarakannya sidang secara online, dan kedua belah pihak yang bersengketa juga dapat memilih untuk melakukan sidang secara fisik. Metode yang digunakan bergantung pada apa yang telah disepakati dan dianggap sebagai metode paling efektif bagi kedua belah pihak.

Peraturan \& Prosedur Arbitrase BANI pada Pasal 14 ayat 4 disini mengatur tentang Tempat Sidang, persidangan diselenggarakan ditempat yang ditetapkan oleh BANI dan kesepakatan para pihak, namun dapat pula ditempat lain jika dianggap perlu oleh Majelis Arbitrase atau Arbiter Tunggal dengan kesepakatan para pihak. ${ }^{32}$ Namun dalam peraturan tersebut tidak diatur secara tegas dan jelas tentang tempat persidangan Pemeriksaan Saksi untuk dapat dilakukan secara online.

Dan sama halnya pada Undang-undang No. 30 Tahun 1999 tentang Arbitrase pengaturan mengenai Sidang Pemeriksaan yang dilakukan secara online tidak ditemukan atau tidak diatur secara jelas.

\section{Putusan Arbitrase}

Jika ingin menyelesaikan suatu sengketa dilembaga arbitrase maka tujuan terpenting dari arbitrase adalah putusan dari lembaga arbitrase tersebut dapat dilaksanakan. Kerahasiaan putusan arbitrase harus dijaga oleh Majelis Arbitrase dan para pihak. SIAC Rules secara jelas menyatakan bahwa Majelis Arbitrase dan para pihak menjaga kerahasiaan semua hal yang berkaitan dengan proses arbitrase dan putusan arbitrase itu sendiri. ${ }^{33}$ Pada prinsipnya, kecuali kedua belah pihak sepakat, kerahasiaan putusan arbitrase harus dijaga dan tidak diungkapkan. Para pihak dapat mengatur kerahasiaan prosedur arbitrase dan membuat keputusan dalam perjanjian arbitrase yang telah disepakati.

Putusan arbitrase tidak memungkinkan untuk dilakukannya upaya banding dan kasasi. Oleh karena itu, putusan arbitrase bersifat Final and Binding. Sama halnya dengan arbitrase online, juga memiliki kekuatan hukum yang bersifat final dan mengikat para pihak yang terlibat didalamnya. Meskipun ada upaya untuk melawan putusan arbitrase, upaya ini sangat terbatas. ${ }^{34}$

Agar dapat diakui dan dilaksanakan, putusan arbitrase harus sah. Namun, tidak semua putusan arbitrase yang sah dapat diakui dan dilaksanakan. Menurut Phillip Capper menyatakan bahwa, keabsahan putusan arbitrase bergantung pada perjanjian arbitrase dan hukum dimana arbitrase itu dilaksanakan. Jika ada perjanjian arbitrase yang tidak sah, maka putusan arbitrase tersebut akan sulit untuk dapat diakui dan dilaksanakan. ${ }^{35}$

Putusan Arbitrase SIAC dibagi menjadi 3 (tiga) macam, yaitu Interim Award (Putusan Sementara) yaitu putusan diputuskan karena berkaitan dengan adanya pembatasan jangka waktu, jawaban para pihak dan kewenangan dari arbitrase tersebut, Interlocutory Award (Putusan Sela) yaitu putusan yang berkaitan dengan tanggung jawab di mana jumlah tuntutan dari Pemohon (Claimant) ditentukan sebagian, dan Putusan Partial Award (Putusan Sebagian) yaitu putusan di mana hanya sebagian tuntutan Pemohon (Claiment) dikabulkan. ${ }^{36}$

Mengenai Putusan Akhir SIAC, putusan akan diambil oleh Tribunal setelah bertemu dengan para pihak yang bersengketa tersebut (Claimant dan Respondent). Tribunal (Majelis Arbitrase) dapat membuat putusan terpisah dalam hal berbeda dan dalam waktu berbeda pula.

Putusan Arbitrase harus disampaikan kepada Panitera SIAC (Registrar of SIAC) yang akan mengatur supaya putusan tersebut dibuatkan salinan autentiknya untuk dikirimkan kepada para pihak setelah pelunasan pembayaran semua biaya dan pengeluaran yang masih tertunggak. ${ }^{37}$

Hal ini menjelaskan bahwa Putusan Arbitrase SIAC dapat dilakukan secara online, karena terdapat kalimat "dibuatkan salinan autentik putusan tersebut untuk dikirimkan kepada para pihak" berarti ada kemungkinan putusan tersebut dapat dikirim secara elektronik yaitu berupa e-mail, faksimili, ataupun perantara post.

Pada SIAC Rules Article 32.8 Rules states yang berbunyi: ${ }^{38}$

The Award shall be delivered to the Registrar, who shall transmit certified copies to the parties upon full settlement of the costs of the arbitration.

Kemudian dalam Arbitration Act of Singapore menjelaskan hal yang sama mengenai putusan arbitrase yang dapat dilakukan secara online, yaitu terdapat pada Section 19B(3) of the Singapore International Arbitration Act relevantly states yang berbunyi: ${ }^{39}$

\footnotetext{
${ }^{32}$ Lihat Pasal 14 ayat 4 Peraturan \& Prosedur Arbitrase BANI

${ }^{33}$ Lihat Article 35.1 Singapore International Arbitration Centre Rules (SIAC Rules)

${ }^{34}$ Munir Fuady, Arbitrase Nasional, (Bandung: PT. Citra Aditya Bakti, 2003). Hal. 99.

${ }^{35}$ Phillip Capper, International Arbitration : a handbook, Edisi ke-3, (London-Singapore: LLP, 2004), hal.117.

${ }^{36}$ Frans Hendra Winarta, Op.Cit., hal.137.

${ }^{37}$ Lihat Article 28.6 Singapore International Arbitration Centre Rules (SIAC Rules)

${ }^{38}$ Lihat Rule 32.8 of the SIAC Rules states
} 
Yongky Pieter Lahema dan Imam Haryanto, Analisis Hukum Pelaksanaan Penyelesaian Sengketa Bisnis dengan Metode Arbitrase Online di Indonesia dan di Singapura

"... an award is made when it has been signed and delivered in accordance with Article 31 of the Model Law."

Dilanjut pada Artticle 31(1) of the UNCITRAL Model Law relevantly states yang berbunyi: ${ }^{40}$

"After the award is made, a copy signed by the arbitrators ... shall be delivered to each party."

Putusan Arbitrase SIAC dapat dilakukan pengiriman secara online dengan syarat bahwa para pihak telah memenuhi syarat administrasinya, lalu Panitera SIAC akan membuatkan salinan autentiknya dan dikirimkan ke para pihak yang bersengketa.

Pada Putusan Arbitrase BANI terdapat 3 (tiga) macam putusan, yaitu, putusan persetujuan perdamaian, putusan sela dan putus akhir. ${ }^{41}$ Berdasarkam Undang-undang No.30 Tahun 1999 tentang Arbitrase mencantumkan sarat-syarat putusan arbitrase, yaitu putusan arbitrase harus memuat data, analisis, kesimpulan dan putusan yang jelas, serta putusan yang tidak kabur. Pengiriman Putusan Arbitrase secara online belum diatur secara jelas dan tegas dalam undang-undang arbitrase Indonesia. Pada Pasal 55 Undang-undang No. 30 Tahun 1999 menyatakan "Apabila pemeriksaan sengketa telah selesai, pemeriksaan segera ditutup dan ditetapkan hari sidang untuk mengucapkan putusan arbitrase" selanjutnya Pasal 57 menentukan "Putusan diucapkan dalam waktu paling lama 30 (tiga puluh) hari setelah pemeriksaan ditutup". Kemudian putusan diucapkan dalam suatu persidangan.

Dalam Peraturan \& Prosedur Arbitrase BANI Pasal 32 penyampaian Putusan Arbitrase dalam waktu 14 (empat belas) hari Putusan yang telah ditanda tangani para arbiter tersebut harus disampaikan kepada setiap pihak, bersama 2 (dua) lembar salinan untuk BANI, dimana salah satu dari salinan itu akan didaftarkan oleh BANI di Pengadilan Negeri yang bersangkutan. ${ }^{42}$

Putusan Arbitrase menurut Peraturan \& Prosedur BANI dapat memungkinkan Putusan Arbitrase dikirim secara elektronik namun memang dalam penjelasan Pasal 32 tersebut masih rancu karena terdapat "2 (dua) lembar salinan" yang dimana kalimat tersebut memiliki makna salinan secara fisik. Dan pada Undang-undang No. 30 Tahun 1999 tentang Arbitrase tersebut tidak mengatur secara jelas mengenai pengiriman Putusan Arbitrase secara online, hanya mengatur Pembacaan Putusan Arbitrase dalam persidangan.

\section{Pelaksanaan Arbitrase online menurut SIAC Rules sebagai model hukum acara arbitrase online di Indonesia.}

Setelah membahas perbandingan mengenai pelaksanaan arbitrase online di Indonesia melalui lembaga BANI dengan Singapura melalui lembaga SIAC, penulis telah menemukan beberapa perbedaan dalam proses pelaksanaan arbitrase online di Indonesia melalui lembaga BANI, pada Peraturan \& Prosedur Arbitrase BANI maupun UndangUndang No. 30 Tahun 1999 tentang Arbitrase tidak adanya peraturan yang mengatur secara jelas salah satunya dalam hal proses Sidang Pemeriksaan dan Putusan Arbitrase. Namun pelaksanaan arbitrase online di SIAC, SIAC Rules, Arbitration Act of Singapore, dan UNCITRAL sudah memiliki pengaturan Sidang Pemeriksaan (Hearing) dan Putusan Arbitrase untuk dilakukan secara online.

Oleh sebab itu penulis ingin memberikan masukan melalui SIAC Rules untuk dapat dijadikan model hukum acara arbitrase online di Indonesia, akankah bertentangan dengan Undang-undang yang belaku di Indonesia.

Pada dasarnya arbitrase online tidak dilarang untuk dilaksanakan dalam menyelesaikan sengketa di Indonesia, hal ini sesuai dengan Pasal 31 ayat 1 Undang-Undang No. 30 Tahun 1999 yaitu: ${ }^{43}$

"Para pihak dalam suatu perjanjian yang tertulis, bebas untuk menentukan pelaksanaan acara arbitrase yang digunakan selama pemeriksaan sengketa sepanjang tidak bertentangan dengan ketentuan dalam UndangUndang."

Ini merupakan prinsip party autonomy, yang memberikan kebebasan penuh kepada para pihak untuk menentukan prosedur arbitrase. ${ }^{44}$ Hanya saja Indonesia belum memiliki regulasi yang jelas untuk mengatur hal tersebut, untuk memberikan landasan hukum kepastian pelaksanaannya. Di Indonesia pada saat ini walaupun telah

${ }^{39}$ Lihat Section 19B (3) of the Singapore International Arbitration Act

${ }^{40}$ Lihat Article 31(1) of the UNCITRAL Model Law

${ }^{41}$ Grasia Kurniati. "Studi Perbandingan Penyelesaian Sengketa Bisnis dan Implementasinya Antara Lembaga Badan Arbitrase Nasional Indonesia dan Singapore International Arbitration Centre", Jurnal Ilmiah Hukum De’Jure: Kajian Ilmiah Hukum Volume 1 Nomor 2, (September 2016).

${ }^{42}$ Lihat Pasal 32 Peraturan \& Prosedur Arbitrase BANI

${ }^{43}$ Lihat Pasal 31 ayat 1 Undang-Undang No. 30 Tahun 1999 tentang Arbitrase dan Alternatif Penyelesaian Sengketa

${ }^{44}$ Moh. Ali dan Yudha Hernoko. "Characterictics of Party Autonomy in a Transnational Electronic Consumer Contract", Yuridika: Volume. 35 No. 1, (Januari 2020). 
Yongky Pieter Lahema dan Imam Haryanto, Analisis Hukum Pelaksanaan Penyelesaian Sengketa Bisnis dengan Metode Arbitrase Online di Indonesia dan di Singapura

memiliki Undang-Undang No. 11 Tahun 2008 tentang Telekomunikasi dan Informasi Elektronik, namun belum mampu memberikan kepastian untuk penyelesaian sengketa secara online. Secara praktik, penyelesaian sengketa dengan cara online ini sudah dilaksanakan, walaupun belum ada aturan baku yang mengatur.

Dalam Sidang Pemeriksaan (Hearing) di SIAC, SIAC Rules Article 21.1, Arbitration Act of Singapore Chapter 10, Act 25(1), UNCITRAL Article 24(1) hampir memiliki pengaturan yang sama mengenai hal tersebut. Pada intinya pengaturan Sidang Pemeriksaan (Hearing) secara online di SIAC, Majelis Arbitrase (Tribunal) dapat mengadakan proses Hearing dengan cara apapun yang dianggap bijaksana atau sesuai dan dilokasi manapun yang dianggap nyaman atau Majelis Arbitrase (Tribunal) dapat mengadakan Proses Hearing dengan mendengarkan pendapat dari saksi-saksi/saksi ahli, atau argumen berdasarkan dokumen dan materi lainnya. Dengan hal tersebut SIAC dapat memungkinkan melakukan Sidang Pemeriksaan (Hearing) dapat dilaksanakan secara online dengan Telephone, Video, Online Hearing. Dan dalam hal barang bukti dapat menggunakan dokumen dan materi lainnya yang berarti dapat juga menggunakan bukti data-data elektronik. Sesuai dengan kesepakatan para pihak bila ingin menjalankan proses Hearing dengan online.

Dalam hal ini di Indonesia melalui lembaga BANI, Sidang Pemeriksaan yang dilakukan secara online, apabila pengaturan Sidang Pemeriksaan di SIAC yang melakukannya secara online, mulai dari persidangan yang dilaksanakan secara online dengan Video Conference, sampai pemeriksaan saksi-saksi menggunakan Telephone, Video, Video Conference, dan pembuktian yang menggunakan bukti data-data elektronik, diadopsi pada hukum acara arbitrase online di Indonesia.

Undang-undang No. 11 Tahun 2008 tentang Informasi dan Transaksi Elektronik pada Pasal 33 melindungi lembaga arbitrase yang akan melaksanakan sidang secara online, karena mengatur mengenai perbuatan yang dilarang, apabila pada saat persidangan ada pihak-pihak yang mengganggu atau berusaha menghentikan jalannya sidang menggunakan fasilitas teknologi informasi, yaitu: "Setiap orang dengan sengaja dan tanpa hak atau melawan hukum tindakan apa pun yang berakibat terganggunya Sistem Elektronik dan/atau mengakibatkan Sistem Elektronik menjadi tidak bekerja sebagaimana mestinya". ${ }^{45}$

Kemudian pada Pasal 41 Undang-undang No. 11 Tahun 2008 tentang Informasi dan Transaksi Elektronik mendukung lembaga penyelesaian sengketa di Indonesia untuk melaksanakan persidangan secara online, karena pada klausul tersebut yang berisikan: “(1) masyarakat dapat berperan meningkatkan pemanfaatan teknologi informasi melalui penyelenggaraan melalui sistem elektronik dan transaksi elektronik. (2) peran masyarakat sebagaimana pada ayat 1 dapat diselenggarakan melalui lembaga yang dibentuk oleh masyarakat. (3) lembaga sebagaimana ayat 2 dapat memiliki fungsi konsultasi dan mediasi. ${ }^{46}$

Dari dua pasal tersebut membuka peluang bahwa pelaksanaan Sidang Pemeriksaan secara online dengan Video Conference, sampai pemeriksaan saksi-saksi menggunakan Telephone, Video, Video Conference seperti yang SIAC lakukan tidak bertentangan dengan hukum di Indonesia, karena masyarakat Indonesia dapat memanfaatkan teknologi informasi melalui lembaga yang dibentuk dan sudah adanya kepastian hukum terhadap perlindungan lembaga penyedia penyelesaian sengketa secara online.

Pembuktian perihal bukti bukti elektronik, pembuktian elektronik sudah diatur melalui Pasal 4 Undang-undang No. 11 Tahun 2008 tentang Informasi dan Teknologi Elektronik, yaitu: "(1) Informasi elektronik memiliki kekuatan hukum sebagai alat bukti yang sah; (2) Bentuk tertulis atau bentuk print out dari informasi elektronik merupakan alat bukti dan memiliki akibat hukum yang sah; (3) Informasi elektronik dinyatakan sah apabila menggunakan sistem elektronik yang dapat dipertanggungjawabkan sesuai dengan perkembangan teknologi informasi." 47

Sehingga alat bukti elektronik dapat diterapkan pada peraturan arbitrase online di Indonesia seperti yang dilakukan oleh SIAC, karena tidak bertentangan dengan hukum maupun norma yang ada di Indonesia.

Selanjutnya hal yang tidak diatur dalam pelaksanaan arbitrase online di Indonesia ialah pengiriman Putusan Arbitrase dengan memanfaatkan teknologi informasi. Putusan Arbitrase secara online akan tetap dianggap sah apabila tidak melanggar unsur-unsur pada Pasal 70 Undang-undang No. 30 Tahun 1999 tentang Arbitrase yang berbunyi: (a) surat atau dokumen yang diajukan dalam pemeriksaan, setelah putusan dijatuhkan, diakui palsu atau tidak dinyatakan palsu; (b) setelah putusan diambil ditemukan dokumen yang bersifat menentukan yang disembunyikan oleh para pihak lawan; atau (c) putusan diambil dari hasil tipu muslihat yang dilakukan oleh salah satu pihak dalam pemeriksaan sengketa. Dengan demikian apabila Putusan Arbitrase online dapat batal demi hukum jika tidak sesuai dengan unsurunsur tersebut. ${ }^{48}$

Kemudian pengiriman Putusan Arbitrase secara online menurut Undang-undang No. 19 Tahun 2016 tentang Informasi dan Transaksi Elektronik pada Pasal 1 angka 4 yang menjelaskan mengenai dokumen elektronik, yang

\footnotetext{
${ }^{45}$ Lihat Pasal 33 Undang-Undang No. 11 Tahun 2008 tentang Informasi dan Transaksi Elektronik

${ }^{46}$ Lihat Pasal 41 Undang-Undang No. 11 Tahun 2008 tentang Informasi dan Transaksi Elektronik

${ }^{47}$ Lihat Pasal 4 Undang-Undang No. 11 Tahun 2008 tentang Informasi dan Transaksi Elektronik

${ }^{48}$ Lihat Pasal 70 Undang-Undang No. 30 Tahun 1999 tentang Arbitrase dan Alternatif Penyelesaian Sengketa
} 
Yongky Pieter Lahema dan Imam Haryanto, Analisis Hukum Pelaksanaan Penyelesaian Sengketa Bisnis dengan Metode Arbitrase Online di Indonesia dan di Singapura

berbunyi: "Dokumen elektronik adalah setiap informasi elektronik yang dibuat, diteruskan, dikirimkan, diterima, atau disimpan dalam bentuk analog, digital, elektromagnetik, optikal atau sejenisnya, yang dapat dilihat, ditampilkan, dan/atau didengar melalui komputer atau sistem elektronik, termasuk tetapi tidak terbatas pada tulisan, suara, gambar, peta, rancangan, foto atau sejenisnya, huruf, tanda, angka, kode akses, simbol atau perforasi yang memiliki makna atau arti dapat dipahami oleh yang mampu memahami." ${ }^{49}$ Dengan demikian, data elektronik dalam segala bentuk informasi elektronik memiliki akibat hukum, keabsahan, dan kekuatan hukum. Hal ini berkaitan dengan pengiriman Putusan Arbitrase secara online.

Sehingga Putusan Arbitrase online dalam bentuk dokumen elektronik dapat tetap memiliki keabsahan/kekuatan hukum yang sama seperti Putusan Arbitrase konvensional, selama tidak melanggar prinsip-prinsip Putusan Arbitrase pada Undang-Undang Arbitrase.

Dengan demikian kekosongan hukum pada peraturan pelaksanaan arbitrase online di BANI dapat mengadopsi atau mencontoh peraturan pelaksanaan arbitrase online di SIAC, sehingga memberikan kepastian kepada para pihak yang ingin menyelesaikan perkara arbitrase secara online di BANI dimasa yang akan datang.

\section{SIMPULAN}

Perbandingan pelaksanaan arbitrase online di SIAC dan di BANI memiliki dasar hukum dan aturannya masing masing. Pelaksanaan arbitrase online di SIAC memiliki peraturan prosedur arbitrase online yang lebih jelas dan lengkap, SIAC dapat melaksanakan arbitrase online karena pada SIAC Rules, Arbitration Act of Singapore dan UNCITRAL yang menjadi landasan hukum pelaksanaan arbitrase di SIAC sudah mengatur secara jelas mengenai pelaksanaan arbitrase online dimulai dari proses Pendaftaran Arbitrase secara online, proses Hearing (Sidang Pemeriksaan) yang dapat dilakukan menggunakan Video Conference atau Telephone dan memberikan bukti-bukti menggunakan data elektronik, sampai Putusan Arbitrase yang dilakukan secara online. Lalu pelaksanaan arbitrase online di BANI memungkinkan untuk melaksanakan arbitrase online, namun hanya saja Peraturan \& Prosedur Arbitrase BANI dan Undang-undang No. 30 Tahun 1999 tentang Arbitrase dan Alternatif Penyelesaian Sengketa yang menjadi landasan hukum pelaksanaan arbitrase di BANI tidak memiliki aturan yang mengatur secara tegas dan jelas. Pada Peraturan \& Prosedur Arbitrase BANI dan Undang-undang No. 30 Tahun 1999 tentang Arbitrase memungkinkan untuk melaksanakan Pendafttaran Arbitrase secara online, namun pada proses berikutnya yaitu Sidang Pemeriksaan online, sampai Putusan Arbitrase online tidak memiliki aturan yang jelas mengenai hal tersebut.

Pengaturan mengenai pelaksanaan arbitrase online di SIAC, dapat diadopsi oleh BANI dan dijadikan hukum acara pelaksanaan arbitrase online di Indonesia. Terutama dalam hal Sidang Pemeriksaan online dan Putusan Arbitrase online, yang di Indonesia tidak memiliki pengaturan mengenai dua hal tersebut. Pada Sidang Pemeriksaan jika dilakukan menggunakan Video Conference atau Telephone dan memberikan bukti-bukti menggunakan data elektronik di Indonesia, menurut Undang-Undang No. 11 Tahun 2008 tentang Informasi dan Transaksi Elektronik memberikan kepastian perlindungan hukum terhadap lembaga yang melakukan persidangan menggunakan Video Conference atau Telephone dan dalam Undang-Undang No. 11 Tahun 2008 tentang Informasi dan Transaksi Elektronik memberikan kesempatan kepada masyarakat untuk memanfaatkan/mengembangkan teknologi informasi untuk digunakan oleh lembaga yang telah dibentuk untuk melakukan persidangan secara online. Bukti-bukti dalam bentuk data elektronik juga memiliki akibat hukum yang sah dan dapat dipertanggung jawabkan dihadapan hukum.

Kemudian Putusan Arbitrase online, Putusan Arbitrase online akan tetap dianggap sah apabila tidak melanggar unsur-unsur Putusan Arbitrase menurut Undang-Undang No. 30 Tahun 1999 tentang Arbitrase dan Alternatif Penyelesaian Sengketa. Pengiriman Putusan Arbitrase secara elektronik menurut Undang-Undang No. 19 Tahun 2016 tentang Informasi dan Transaksi Elektronik tetap memiliki akibat hukum, keabsahan/kekuatan hukum untuk para pihak yang bersengketa.

Sehingga pengaturan arbitrase online di SIAC, dapat diadopsi oleh BANI maupun Undang-Undang Arbitrase Indonesia karena tidak bertentangan dengan Undang-Undang lain maupun norma yang ada di Indonesia.

\section{DAFTAR PUSTAKA \\ Buku}

Capper, Phillip. International Arbitration: a handbook, Edisi ke-3. London-Singapore: LLP, 2004.

Fuady, Munir. Arbitrase Nasional. Bandung: PT. Citra Aditya Bakti, 2003.

Harahap, Yahya. M. Arbitrase, Cetakan ke-3, Edisi ke-2. Jakarta: Sinar Grafika 2004.

H.S. Salim. Hukum Kontrak Teori Teknik Penyusunan Kontrak, Cet. Ke-3. Jakarta: Grafika 2006.

Kaufmann-Kohler, Gabrielle, dan Schultz, Thomas. Online Dispute Resolution: Challenges For Contemporary Justice. Kluwer Law Internasional: The Netherlands, 2004. 
Yongky Pieter Lahema dan Imam Haryanto, Analisis Hukum Pelaksanaan Penyelesaian Sengketa Bisnis dengan Metode Arbitrase Online di Indonesia dan di Singapura

Margono, Suyud. Penyelesaian Sengketa Bisnis: Alternatif Dispute Resolutions (ADR). Bogor: Ghalia Indonesia, 2010.

Redfern, Alan. dan J. Martin Hunter. Redfern and Hunter on International Arbitration, edisi keenam. Inggris: Oxford University Press, 2015.

Siburian, Paustinus. Arbitrase Online (Alternatif Penyelesaian Sengketa Perdagangan Secara Elektronik. Jakarta: Tatanusa, 2004.

Soekanto, Soerjono, dan Sri Mamudji. Penelitian Hukum Normatif, Cetakan ke-8. Jakarta: PT. Raja Grafindo Persada, 2004.

Suparman, Eman. Pilihan Forum Arbitrage Dalam Sengketa Komersil (untuk Penegakan Keadilan). Jakarta: Tatanusa, 2004.

Ustadiyanto, Riyeke. Framework E-commerce. Bandung: Andi Offset, 2002.

Winarta, Frans Hendra. Hukum Penyelesaian Sengketa Arbitrase Nasional dan Internasional, Edisi ke-2. Jakarta: Sinar Grafika,, 2016.

\section{Jurnal}

Doug Jones, "Comments on the Speech of the Singapore Attorney General", dalam International Arbitration: The Coming of a New Age?". 2013.

Grasia Kurniati. "Studi Perbandingan Penyelesaian Sengketa Bisnis dan Implementasinya Antara Lembaga Badan Arbitrase Nasional Indonesia dan Singapore International Arbitration Centre”, Jurnal Ilmiah Hukum De'Jure: Kajian Ilmiah Hukum Volume 1, Nomor 2, (September 2016) : 202.

Moh. Ali dan Yudha Hernoko. "Characterictics of Party Autonomy in a Transnational Electronic Consumer Contract", Yuridika: Volume. 35 No. 1, (Januari 2020) : 55.

\section{Skripsi/Thesis/Disertasi}

H.M Erham Amin dan Mulyani Zulaeha. "Penyelesaian Sengketa Perdata Melalui Arbitrase Online Dalam Konstruksi Undang-Undang Nomor 30 Tahun 1999 tentang Arbitrase dan Alternatif Penyelesaian Sengketa". Thesis Pascasarjana, Magister Ilmu Hukum, Universitas Lambung Mangkurat, (2011).

\section{Seminar}

Kendista Wantah, S.H., FCIArb. Counsel SIAC Secretariat. "SIAC Arbitration - Protect the Company, Keep Control, Get The Best Result Save Money". Paper dipresentasi kan saat seminar Mediasi \& Arbitrase Dalam Penyelesaian Sengketa Bisnis (Best Practice Di Indonesia \& Singapura), Bismark Business \& Law Consultan dan UPN Veteran Jakarta, pada 11 September 2020.

\section{Peraturan Perundang-Undangan}

Arbitration Act of Singapore (Chapter 10)

Peraturan \& Prosedur Arbitrase BANI 2018

UNCITRAL Model Law

Undang-Undang Nomor 30 Tahun 1999 tentang Arbitrase dan Alternatif Penyelesaian Sengketa

Undang-Undang Nomor 11 Tahun 2008 tentang Informasi dan Transaksi Elektronik

Undang-Undang Nomor 19 Tahun 2016 tentang Informasi dan Transaksi Elektronik

Singapore International Arbitration Centre Rules 2016 (SIAC Rules 2016)

\section{Internet}

Asosiasi Penyelenggara Jasa Internet Indonesia, Statistik Indonesia Users, https://www.apjii.or.id/content/read/39/410/Hasil-Survei-Penetrasi-dan-Perilaku-Pengguna-Internet-Indonesia2018.

Hukum Online, Penyesuaian Pelaksanaan Proses Arbitrase Kala Pandemi Covid-19 Oleh: Harri Budiman \& Maria Ulfa, https://www.hukumonline.com/berita/baca/lt5fe2c3fab0c93/penyesuaian-pelaksanaan-proses-arbitrasekala-pandemi-covid-19-oleh--harri-budiman-maria-ulfa?page=all.

SIAC, “Rules", https://www.siac.org.sg/our-rules, diakses tanggal 23 Januari 2021 Pukul 19:01 WIB.

Hukum Online, "Simak, Delapan Perubahan Aturan Terbaru dalam SIAC Rules 2016", https://www.hukumonline.com/berita/baca/lt582d38404424c/simak--delapan-perubahan-aturan-terbaru-dalam$\underline{\text { siac-rules-2016/. }}$. 